\title{
Análise da interface formada entre o polifluoreto de vinilideno (piezelétrico e não piezelétrico) e o tecido ósseo de ratos
}

\author{
Analysis of the interface formed among the poli (vinilidene) fluoride (piezoelectric and non- \\ piezoelectric) and the bone tissue of rats
}

Bianca Callegari', Dr William Dias Belangero²

\section{RESUMO}

O objetivo deste estudo foi analisar a interface formada entre o polifluoreto de vinilideno (PVDF - piezelétrico e não piezelétrico) e o tecido ósseo do rato. Foram implantados em 40 ratos, na região intercondiliana do fêmur esquerdo, vinte tubos de PVDF [P(VDF-TrFE)] piezelétricos, $\left(\mathrm{d}_{3 \mathrm{~h}}=2,5 \mathrm{pC} / \mathrm{N}\right.$ e capacitância $\left.800 \mathrm{pF} / \mathrm{m}\right)$, e vinte tubos de PVDF não piezelétricos. Os animais de ambos os grupos foram subdivididos em quatro subgrupos, seguidos por 7 dias, 3, 6 e 12 semanas. A interface formada pelos tubos com o tecido ósseo foi estudada por microscopia óptica convencional (MOC) $(n=28)$ e pela microscopia eletrônica de varredura (MEV) por retroespalhamento $(n=12)$. No interior dos tubos de PVDF piezelétricos seguidos por 12 semanas foi constatado, tanto pela MOC como pela MEV por retroespalhamento, crescimento de tecido ósseo. Os resultados indicam que a piezeletricidade teve papel importante na neoformação do tecido ósseo no interior dos tubos piezelétricos. Provavelmente, essa formação óssea foi decorrente ou do efeito eletreto, ou das microdeformações produzidas nos tubos piezelétricos, devido à variação da pressão intra articular do joelho durante a marcha.

Descritores: Piezeletricidade; Crescimento ósseo; Implantes artificiais

\section{INTRODUÇÃO}

A piezeletricidade é uma propriedade presente em materiais no estado cristalino. Materiais biológicos ricos em colágeno, como o osso e o tendão, podem apresentar essa propriedade que, de alguma forma, seria responsável pela adaptação desses tecidos às solicitações mecânicas que o meio externo impõe ${ }^{(3)}$.

O efeito da piezeletricidade foi estudado em nosso meio por Köberle $^{(9)}$ em sua tese de livre-docência. Yasuda ${ }^{(15)}$ também estudou o efeito da piezeletrecidade aplicando Teflon (polarizado e não polarizado eletricamente) sobre a superfície do fêmur e enrolado ao redor deste osso em coelhos. Observou que abaixo do Teflon não polarizado

\section{SUMMARY}

The objective of this study was to evaluate the interface formed between the poli (viniilidene) fluoride (PVDF-piezoelectric and non-piezoelectric) and cap rats' bone tissue. Twenty tubes of PVDF [P NDFTrFE)] piezoelectric, $\left(d_{3 h}=2,5 \mathrm{pC} / \mathrm{N}\right.$ and capacitance $\left.800 \mathrm{pF} / \mathrm{m}\right)$, and twenty tubes of non-piezoelectric PVDF were implanted in the intercondilian notch of the left femur of 40 rats. The animals of both groups were subdivided in four subgroups, followed up for 7 days, 3, 6 and 12 weeks. The interface found between bone and tubes was studied by conventional optical microscopy (MOC) $(n=28)$ and by backscattered electronic scanning microscopy (MEV) $(n=12)$. Bone tissue growth was observed inside the tubes of piezoelectric PVDF followed up during 12 weeks, both by MOC and by MEV backscattering.

The results indicate that the piezoelectric effect had an important role in the new bone tissue formation inside the piezoelectric tubes. Probably, that bone formation was a result from the electrets effect or from micro deformations produced in the piezoelectric tubes, due to the intra-articular pressure variation on the knee movement during gait.

Key words: Piezoelectric effect, Bone growth, Artificial implants

\section{INTRODUCTION}

The piezoelectricity is a property present in the materials in their crystalline state. Biological material rich in collagen, such as bone and tendon, may show this property which, in a certain way, would be responsible for the adaptation of these tissues to the mechanical demands that the outside environment imposes ${ }^{(3)}$.

The effect of the piezoelectricity was studied in our area by Köber$l^{\left({ }^{(9)}\right.}$ in his free-teaching thesis. Yasuda ${ }^{(15)}$ also studied in rabbits the effect of the piezoelectricity applying Teflon (electrically polarized and non-polarized) on the surface of the femur and rolled up around this bone. He observed that below the non-polarized Teflon there was no bone growth, while around the polarized Teflon there was a formation of bone callus, mainly in those in that Teflon had been rolled up around of the femur.
Trabalho realizado no Laboratório de Investigação em Materiais Ortopédicos (LABIMO) - Departamento de Ortopedia e Trtaumatologia Faculdade de Ciências Médicas - UNICAMP

1 - Pós-Graduanda em Cirurgia, área de Pesquisa Experimental 2 - Coordenador Laboratório de Investigação em Materiais Ortopédicos (LABIMO) do Departamento de Ortopedia e Traumatologia da Faculdade de Ciências Médicas da UNICAMP

Endereço para correspondência: Rua Emílio Ribas no. 800, apto 1, Cambuí - 13025-041 - Campinas/SP - email: belanger@fcm.unicamp.br
Work performed at the Laboratory of Investigation in Orthopedic Materials (LABIMO)-Department of Orthopedics and TraumatologyUniversity of Medical Sciences - UNICAMP

1 - Post-Graduate in Surgery, area of Experimental Research 2 - Manager of laboratory

Address: Rua Emílio Ribas no. 800, apto 1, Cambuí 13025-041 - Campinas/SP

E-mail: belanger@fcm.unicamp.br

Trabalho recebido em 15/04/2004. Aprovado em 20/06/2004. 
não havia ocorrido crescimento ósseo, enquanto que ao redor do Teflon polarizado havia formação de calo ósseo, principalmente naqueles em que o Teflon havia sido enrolado ao redor do fêmur.

Mais recentemente, Jiaqing et al. (5) compararam o efeito da cerâmica não piezelétrica e piezelétrica sobre a neoformação óssea nas mandíbulas de cães. Observaram crescimento ósseo ao redor dos implantes piezelétricos após uma semana, enquanto que após duas semanas não havia ainda neoformação óssea ao redor dos implantes não piezelétricos.

Levando-se em consideração que há indícios de que a piezeletricidade exerce influência no crescimento ósseo, a utilização de materiais com esta característica como implante ósseo parece ser promissora.

O polifluoreto de vinilideno, também conhecido como fluoreto de vinilideno (PVDF), é um polímero semicristalino (50\% cristalino, 50\% amorfo), cuja unidade básica é o $\mathrm{F}_{2} \mathrm{C}=\mathrm{CH}_{2}$. Por apresentar essa composição química, o PVDF pode ser polarizado. Os átomos de Hidrogênio $(H)$ são carregados positivamente, enquanto que os de flúor $(F)$ são carregados negativamente, em relação aos átomos de carbono (C). O PVDF pode ser encontrado sob diferentes formas cristalinas, sendo a forma alfa a mais comum, porém esta forma não é polar. A fase b, por outro lado, pode ser polarizada e apresenta, portanto, propriedades piezelétricas, sendo normalmente obtida da forma alfa, por estiramento mecânico ${ }^{(13)}$.

Do ponto de vista clínico, o PVDF é um polímero utilizado como material de sutura nas cirurgias vasculares. Apresenta, inclusive, desempenho biológico e mecânico superior ao polipropileno, por ser mais biocompatível e por conservar a sua resistência mecânica em até $92,5 \%$ após 9 anos de implantação, enquanto que o polipropropileno perde $46 \%$ dessa resistência nesse mesmo período ${ }^{(8,10)}$

Apesar dessas características, existem poucos estudos que tenha avaliado a potencialidade desse material para a produção de implantes ortopédicos. Em nosso meio, Paschoal(12) demonstrou que membranas de PVDF polarizadas, quando implantadas entre a cortical lateral do fêmur de coelho e uma placa metálica, estimularam o crescimento ósseo. Em função dessas considerações teóricas é cabível se estudar o efeito de implantes de PVDF piezelétricos no tecido ósseo.

\section{MATERIAL E MÉTODO}

Foram utilizados 20 tubos de PVDF [P(VDF-TrFE)] piezelétricos e 20 tubos do mesmo material, não piezelétricos, cedidos pelo Departamento de física, Química e Biologia da Faculdade de Ciência e Tecnologia da UNESP.

Os tubos piezelétricos com coeficiente de $\mathrm{d}_{3 \mathrm{~h}}=2,5 \mathrm{pC} / \mathrm{N}$ e capacitância 800 pF/m foram cortados com comprimento de 5 mm, diâmetro externo de $1,9 \mathrm{~mm}$ e diâmetro interno de 0,8 $\mathrm{mm}^{\circledR 1}$.

A partir dos tubos piezelétricos fundidos à temperatura de $150^{\circ} \mathrm{C}$, obtiveram-se os tubos não piezelétricos, com $5 \mathrm{~mm}$ de comprimento, $2 \mathrm{~mm}$ de diâmetro externo e $0,7 \mathrm{~mm}$ de diâmetro interno.

\section{Animais de experimentação}

Foram utilizados 40 Rattus Novergicus da varidade Wistar, machos, fornecidos pelo Biotério Central da UNICAMP. Os procedimentos foram autorizados pelo Comitê de Ética em Experimentação animal do Instituto de Biologia da UNICAMP.
More recently, Jianqing et al.(5) compared the effects of non-piezoelectric and piezoelectric ceramic on the new formation of bone in the jaws of dogs. Bone growth was observed around of the piezoelectric implants after one week, while after two weeks there still was no new formation of bone around of the no piezoelectric implants.

Taking into account that there are indications that the piezoelectricity exercises influence on bone growth, the use of materials with this characteristic as a bone implant seems to be promising.

The poli (vinililidene) fluoride, also known as vinilidene fluoride (PVDF), is a semi-crystalline polymer (50\% crystalline, $50 \%$ amorphous), whose basic unit is the $\mathrm{F} 2 \mathrm{C}=\mathrm{CH} 2$. PVDF can be polarized because it presents that chemical composition. The atoms of Hydrogen $(H)$ are charged positively, while the fluorine (F) ones are charged negatively, in relation to the atoms of carbon (C). The PVDF may be found under different crystalline forms; although it is not a polar form, alpha is the most common of these forms. On the other hand, the b phase can be polarized, and thus presents, the piezoelectric properties, normally obtained from the alpha form, by mechanical stretching ${ }^{(13)}$.

From the clinical standpoint, PVDF is a polymer used as suture material in vascular surgeries. It also shows a superior biological and mechanic performance in relation to the polypropylene because it is more biocompatible, and because it preserves its mechanical resistance up to 92,5\% after 9 years of the implant, while polypropylene loses $46 \%$ of this resistance during the same period $(8,10)$.

Notwithstanding these characteristics, there are few studies that evaluated the potentiality of this material for the production of orthopedic implants. Within our area, Paschoa/(12) demonstrated that polarized PVDF membranes, when implanted between the cortical lateral of the femur of a rabbit and one metallic plate, it stimulated the bone growth. Due to these theoretical considerations, it is possible to study the effects of piezoelectric PVDF implants on the bone tissue.

\section{MATERIAL AND METHOD}

Twenty piezoelectric PVDF [PNDF-TrFE)] tubes and 20 tubes of the same material, butnon-piezoelectric, were made available by the Physics, Chemistry and Biology Department of the Sciences and Technology College of the UNESP.

The piezoelectric tubes with a $d_{3 h}=2,5 \mathrm{pC} / \mathrm{N}$ coefficient and a capacitance of $800 \mathrm{pF} / \mathrm{m}$ were cut along the length, and were $5 \mathrm{~mm}$ long, with an external diameter of 1,9 $\mathrm{mm}$ and internal diameter of 0,8 $\mathrm{mm}^{\circledR 1}$.

The non-piezoelectric tubes were obtained from the piezoelectric tubes blended at a temperature of $150^{\circ} \mathrm{C}$, with $5 \mathrm{~mm}$ length, $2 \mathrm{~mm}$ external diameter and $0,7 \mathrm{~mm}$ internal diameter.

\section{Experimentation animals}

Forty male Rattus Novergicus of the Wistar variety were used, supplied by Central Biotery of the UNICAMP. The procedures were authorized by the Ethics Committee for Animal Experimentation of the Institute of Biology of UNICAMP.

Twenty piezoelectric tubes were implanted in twenty animals, and 20 non-piezoelectric tubes were implanted in other 20 animals, all in the intercondilian area of the femur. In each group, the 20 animals were divided into four subgroups, followed during 7 days (5 animals), 3 and 6 weeks and 12 weeks (5 animals). 
Em 20 animais foram implantados 20 tubos piezelétricos e nos outros 20 foram implantados 20 tubos não piezelétricos, todos na região intercondiliana do fêmur. Em cada grupo, os 20 animais foram divididos em quatro subgrupos, seguidos por 7 dias (5 animais) 3 e 6 semanas e 12 semanas (5 animais).

\section{Procedimento cirúrgico}

Após jejum pré-operatório, os animais foram anestesiados com Pentobarbital sódico ${ }^{\circledR(2)}$ intravenoso na dose $50 \mathrm{mg} / \mathrm{Kg}$. A região intercondiliana foi exposta por acesso parapatelar lateral. Os tubos foram implantados na região intercondiliana do fêmur da pata esquerda dos ratos, utilizando-se broca de diâmetro idêntico ao dos tubos com furadeira de baixa rotação ${ }^{\circledR(3)}$. A profundidade do furo foi de $5 \mathrm{~mm}$, de modo a manter a superfície do tubo rente a superfície articular.

Decorrido o tempo de seguimento, os animais foram sacrificados por overdose de Pentobarbital sódico e o terço distal dos fêmures da pata esquerda foram retirados. Todas as amostras foram fixadas em solução de formaldeido 10\% não tamponado por 24 horas, com exceção de 3 animais de cada grupo com tempo de seguimento de 6 e 12 semanas, que permaneceram em solução alcoólica $70 \%$ por 24 horas.

Após a fixação, todas as amostras retiradas dos grupos com 7 dias e 3 semanas de seguimento foram descalcificados em solução de ácido nítrico 3\% por 3 dias e foram bivalvadas para a retirada dos tubos, com o mínimo de lesão das amostras. As amostras sem os tubos foram preparadas para análise histológica e os cortes obtidos foram corados com Hematoxilina Eosina e Tricômico de Masson.

Das amostras retiradas dos grupos com tempo de seguimento de 6 e 12 semanas, três amostras de cada um destes grupos foram embutidas em resina acrílica ${ }^{\circledR 4}$ e submetidas à Microscopia Eletrônica de Varredura (MEV) por retroespalhamento para avaliação da interface formada entre o polímero e o osso (Quadro 1).

\section{RESULTADOS}

\section{Análise macroscópica}

A cicatrização da pele e dos tecidos moles foi evidente a partir do sétimo dia e pode se verificar que o animal deambulava sem restrições. A superfície articular da região intercondiliana foi observada durante o sacrifício dos animais e constatou-se que essa superfície era mais regular nos animais em que haviam sido implantados os tubos piezelétricos (Figura 1).

\section{Surgical procedure}

After the preoperative fast, the animals were anesthetized with intravenous sodium Pentobarbita/ ${ }^{\circledR 2}$ in the dosage of $50 \mathrm{mg} / \mathrm{Kg}$. The intercondilian area was exposed by a parapatelar lateral access. The tubes were implanted in the intercondilian area of the femur of the left paw of the mice, using bears with diameters identical to the diameters of the tubes with a low rotation drill ${ }^{\circledR(3)}$. The depth of the hole was of 5 $\mathrm{mm}$, in such a way as to maintain the surface of the tube even with the articular surface.

After the termination of the follow-up period, the animals were sacrificed through an overdose of sodium Pentobarbital, and the third distal of the femurs of the left paw were removed. All of the samples were fixed in formaldehyde $10 \%$ solution of the tamponade for 24 hours, except for 3 animals of each group with a follow-up period of 6 and 12 weeks, that remained in an alcoholic solution at $70 \%$ for 24 hours.

After the fixation, all the samples removed from the groups with a follow-up period of 7 days and 3 weeks were decalcified in a nitric acid solution at 3\% during 3 days, and were bivalved for the removal of the tubes, with a minimum lesion to the samples. The samples, without the tubes, were prepared for the histological analysis and the sections obtained were tinted with Hematoxylin Eosin and Masson Trichomycous.

Three samples removed from each one of the groups with a followup period of 6 and 12 weeks, were incrusted with acrylic resin ${ }^{\circledR(4)}$ and submitted to a retro spreading Electronic Microscopy of Scanning (EMS) for the evaluation of the interface formed between the polymer and the bone (Picture 1).

\section{RESULTS}

\section{Macroscopic analysis}

The cicatrisation of the skin and of the soft tissues was from the seventh day on, and it was observed that the animal strolled without restrictions. The articular surface of the intercondilian area was observed during the sacrifice of the animals and it was verified that that surface was more regular in the animals in that had been implanted with the piezoelectric tubes (Figure 1).

\begin{tabular}{|c|c|c|c|c|c|c|}
\hline \multirow[t]{2}{*}{$\begin{array}{l}\text { Tipo do PVDF } \\
\text { Implantado } \\
\text { Type of PVDF } \\
\text { Implanted }\end{array}$} & \multicolumn{6}{|c|}{$\begin{array}{l}\text { Tempo de seguimento dos animais } \\
\text { e tipo de análise histólógica realizada } \\
\text { Time of follow-up of the animals and } \\
\text { type of histological analysis performed }\end{array}$} \\
\hline & $\begin{array}{c}7 \text { dias } \\
7 \text { days } \\
\text { MOC }\end{array}$ & $\begin{array}{c}\text { 3 semanas } \\
3 \text { weeks } \\
\text { MOC }\end{array}$ & $\begin{array}{r}6 \mathrm{ser} \\
6 \mathrm{w} \\
\mathrm{MOC}\end{array}$ & $\begin{array}{l}\text { lanas } \\
\text { eks } \\
\text { MEV }\end{array}$ & $\begin{array}{l}12 \text { sen } \\
12 \mathrm{we} \\
\text { MOC }\end{array}$ & $\begin{array}{l}\text { lanas } \\
\text { eks } \\
\text { MEV }\end{array}$ \\
\hline Piezelétrico & 5 & 5 & 2 & 3 & 2 & 3 \\
\hline \multicolumn{7}{|l|}{ Piezoeletric } \\
\hline Não Piezelétrico & 5 & 5 & 2 & 3 & 2 & 3 \\
\hline \multicolumn{7}{|l|}{ Non Piezoeletric } \\
\hline Total & 10 & 10 & 4 & 6 & 4 & 6 \\
\hline
\end{tabular}

MOC = microscopia eletrônica convencional; MEV = microscopia eletrônica de varredura

$M O C=$ conventional electronic microscopy; $M E V=$ electronic microscopy by scanning
Quadro 1 - Distribuição dos animais em função do material implantado, tempo de seguimento e análise histológica realizada.

Picture 1 - Distribution of the animals in function of the implanted material, time of follow-up and performed histological analysis

\$2 FONTOVETER - Divisão veterinária de Cristália, produtos químicos e farmacêuticos Rod ltapira- Lindóia km 14 Itapira- SP
s3 BOSCH Switzerland - $130 \mathrm{rpm}$

of Resina Orto centerpol 603 S/UV. Fiber Center Indústria e Comércio 


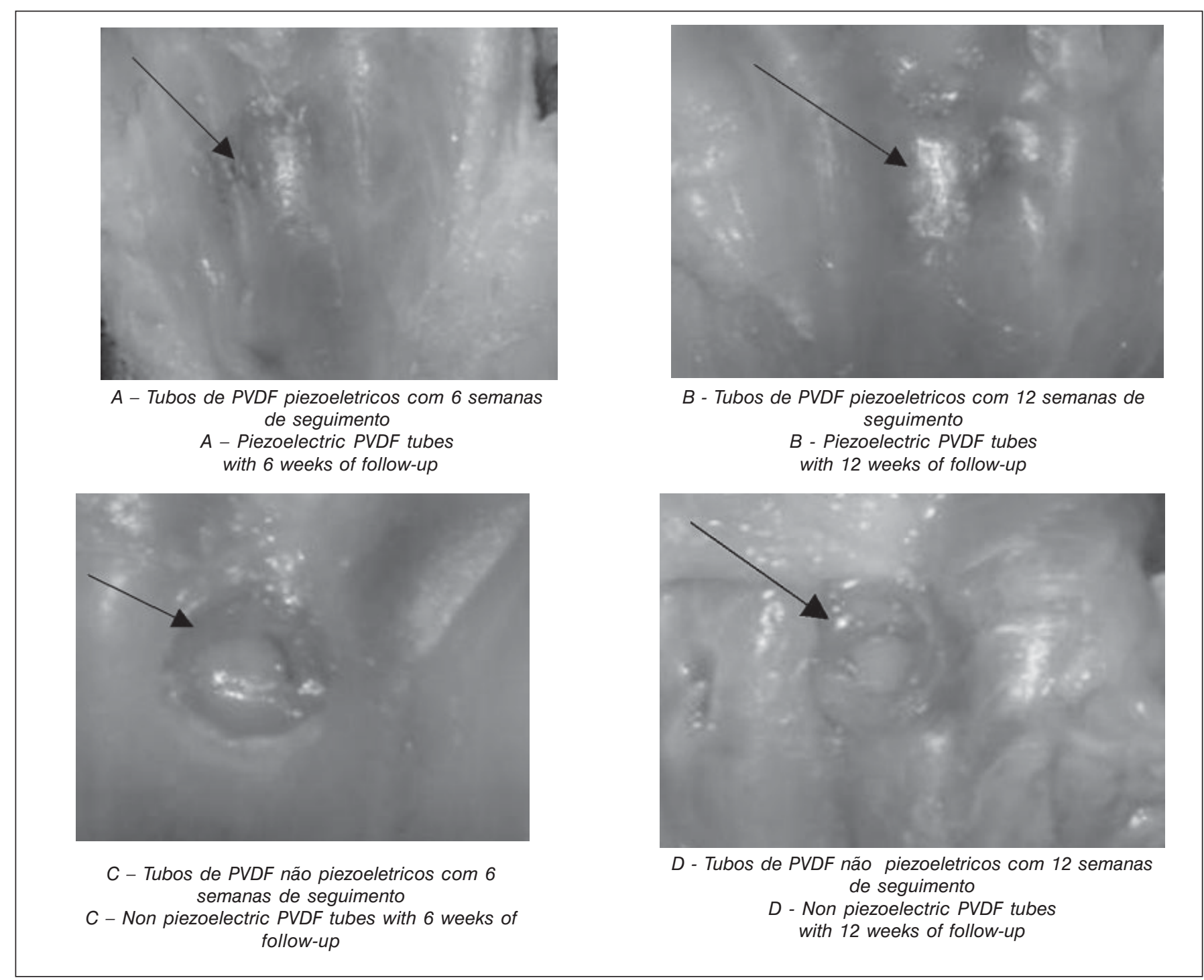

Figura 1 - As ilustrações mostram o preenchimento das cavidades com 6 e 12 semanas de seguimento, com tubos piezelétricos e não piezelétricos

Figure 1 - The illustrations show the completion of the cavities with 6 and 12 weeks of follow-up, with piezoelectric and non-piezoelectric tubes.

A análise histológica das amostras com 7 dias, 3, 6 e 12 semanas $(n=14)$ mostrou que não houve formação de cápsula fibrosa ao redor dos implantes em ambos os grupos. A retirada dos tubos de PVDF polarizados do tecido ósseo foi mais difícil, por estarem mais aderidos.

Nas lâminas obtidas do grupo de 12 semanas $(n=2)$ pôde se observar formação de um halo envolvendo toda a superfície interna e externa dos tubos, com aspecto de tecido ósseo (Figura 2). Nos animais nos quais foram implantados os tubos de PVDF não piezelétricos não foi observado crescimento de tecido ósseo.

A Microscopia eletrônica de varredura por feixe retroespalhado mostrou que a interface formada entre os tubos e o osso era constituída essencialmente por tecido ósseo. No interior dos tubos de PVDF piezelétricos seguidos por 12 semanas $(n=3)$ houve crescimento de tecido ósseo, ao passo que nos interior dos tubos não piezelétricos não foi observado crescimento desse tecido neste mesmo período (Figura 3).
The histological analysis of the samples with 7 days, 3, 6 and 12 weeks ( $n=14$ ) showed that there was no formation of a fibrous capsule around of the implants in both groups. The removal of the tubes of polarized PVDF from the bone tissue was more difficult, because they were more adhered.

The formation of a halo, involving the whole internal and external surface of the tubes, was observed on the laminae obtained from the group of 12 weeks ( $n=2)$, with the aspect of bone tissue (Figure 2). No bone tissue growth was observed in the animals implanted with the non-piezoelectric PVDFtubes.

The electronic Microscopy scanning by retrospread beam showed that the interface formed between the tubes and the bone was constituted essentially from bone tissue. Inside the piezoelectric PVDF tubes followed up for 12 weeks ( $n=3$ ) there was a growth of bone tissue, while, during the same period, the growth of that tissue was not observed inside of the non-piezoelectric tubes (Figure 3). 


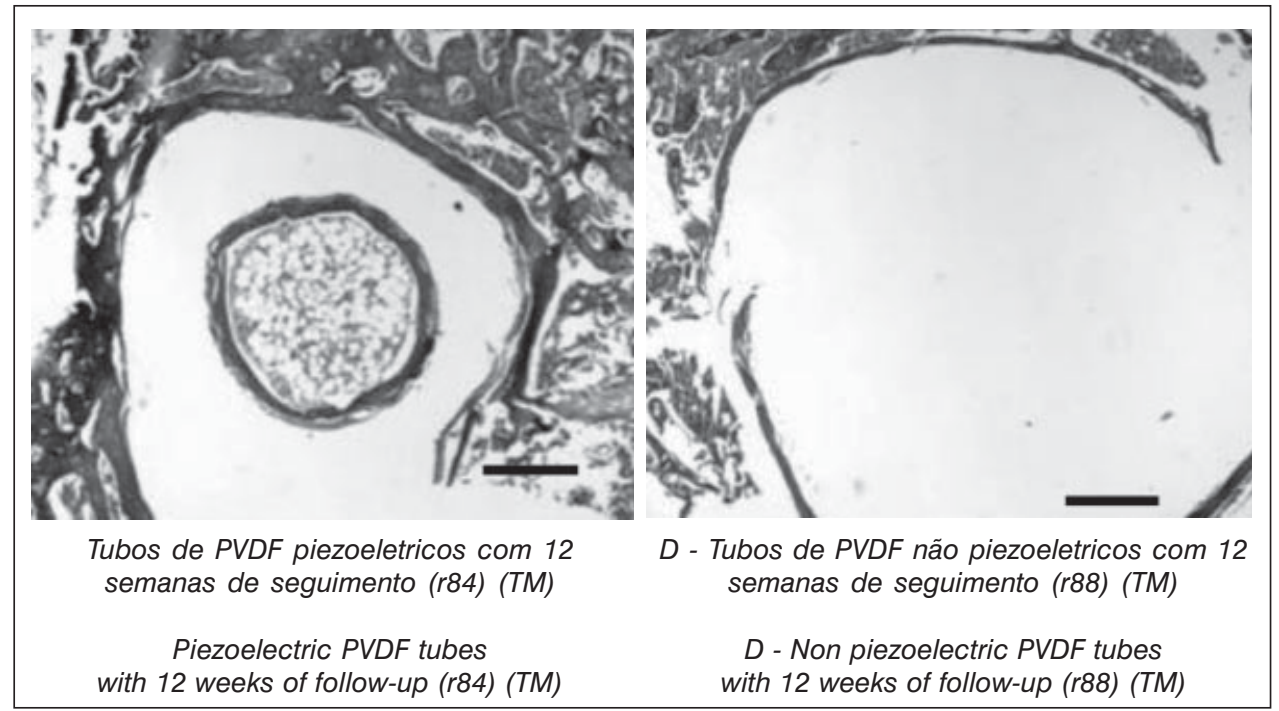

Figura 2 - Cortes histológicos transversais do tecido ósseo, corados com tricrômico de Masson, após retirada dos tubos de PVDF piezoeletricos (à esquerda) e não piezelétricos (à direita). (50x) Barra $=0,33 \mathrm{~mm}$.

Figure 2 - Traverse histological cuts of the bone tissue, tinted with Masson trichomic, after the removal of the piezoelectric PVDF tubes (to the left) and non-piezoelectric tubes (to the right). (50x) Bar $=0,33 \mathrm{~mm}$.

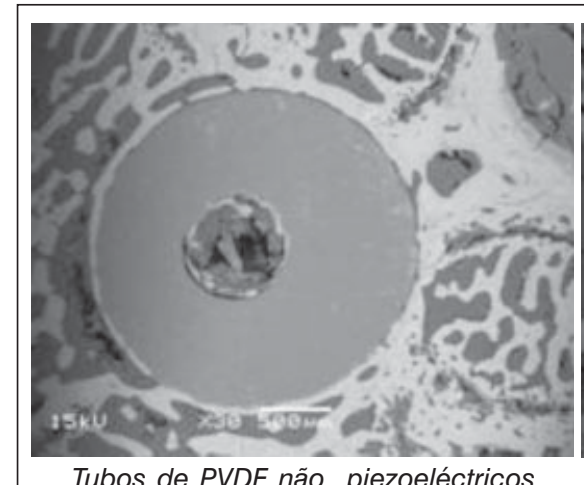

Tubos de PVDF não piezoeléctricos 12 semanas

Non piezoelectric PVDF tubes 12 weeks

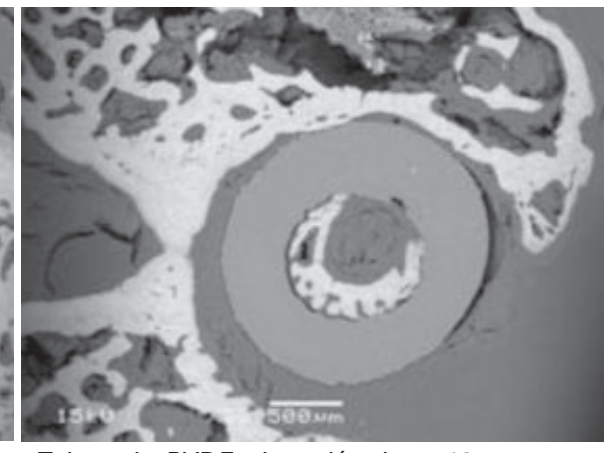

Tubos de PVDF piezoeléctricos 12 semanas

Piezoelectric PVDF tubes 12 weeks

Figura 3 - Imagens da microscopia eletrônica de varredura por retroespalhamento da extremidade distal do fêmur, com tubos piezelétricos (direita) e não piezelétricos (esquerda), após 12 semanas de seguimento. Nota-se à direita que há no interior do tubo imagem compatível com tecido ósseo, incluisive com estrutura trabecular. (aumento)

Figure 3 - Images of the electronic microscopy by retro spreading scanning of the distal extremity of the femur, with piezoelectric tubes (right) and non-piezoelectric tubes (left), after

12 weeks of follow-up. It can be noticed on the right side that there is, inside of the tube,

and image compatible with bone tissue, including a trabecular structure. (I increase)

\section{DISCUSSÃO}

Dos resultados analisados, alguns achados merecem ser destacados: o aspecto mais uniforme e regular da superfície articular da região intercondiliana com tubos piezelétricos; a dificuldade de se retirar os tubos piezelétricos do leito ósseo e, finalmente, o encontro de tecido ósseo apenas no interior dos tubos piezelétricos. Estes encontros sugerem que a piezeletricidade deve ter influenciado esse comportamento, já que tanto os tubos piezelétricos como os não piezelétircos tinham a mesma origem, composição química e acabamentos superficiais.

\section{DISCUSSION}

Some findings from the results analyzed must be underlined: the more uniform and regular aspect of the articular surface of the intercondilian area with the piezoelectric tubes; the difficulty of removing the piezoelectric tubes from the bone bed and, finally, the discovery of bone tissue just inside the piezoelectric tubes. These findings suggest that the piezoelectricity must have influenced that behavior, since the piezoelectric tubes, as much as the non-piezoelectric tubes, had the same origin, chemical composition and superficial linings. 
A forma como o tecido ósseo interpreta o estímulo piezelétrico e o transforma em atividade biológica é ainda pouco esclarecido na literatura, tanto pela dificuldade de se mimetizar as reais condições ambientais do tecido ósseo, como pelo fato de que o conhecimento dos mecanismos de comunicação intra e extracelular é um tema relativamente recente. Os estudos da biologia das últimas décadas têm sido dirigidos ao conhecimento das moléculas extracelulares de sinalização, pois através dessas as células se tornam capazes de responder a determinados estímulos. Estas moléculas de sinalização se ligam a proteínas-receptoras da superfície celular e posteriormente a proteínas sinalizadoras intracelulares, que encaminham o sinal a partes apropriadas da célula. No final deste processo estão as proteínasalvo, que são as efetoras finais e induzem a modificação no comportamento celular ${ }^{(1)}$

Estudos experimentais têm tentado definir qual é a molécula ou sistema que traduz a linguagem do estímulo físico em linguagem biológica, mas até o momento os dados mais atuais sobre o assunto foram definidos baseados em estudos experimentais de cultura de células que, embora sejam muito úteis para esclarecimento de fenômenos isolados, não podem ser extrapolados para o que acontece com o tecido no organismo como um todo. De acordo com Roy et al. ${ }^{(14)}$, os estudos realizados nos últimos 10 anos somente começaram a elucidar os aspectos de sinalização transmembrana e a expressão gênica do tecido ósseo em resposta a estímulos biofísicos, como por exemplo, a alteração de fluxo nos canalículos que unem os osteócitos

A deformação mecânica em níveis fisiológicos pode criar diferentes gradientes de pressão hidrostática no fluido intersticial dos canalículos do tecido ósseo, que são captados pela membrana celular do osteócito, resultando em aumento da atividade metabólica desta, sugerindo que o osteócito é a célula responsável pelo processo de transdução do estímulo mecânico em biológico. Por outro lado, os estudos in vivo ou in vitro têm mostrado também resposta bastante uniforme do tecido ósseo com relação aos estímulos elétricos, que aumentam a produção e a remodelação óssea. Também, o uso terapêutico dessas técnicas, incluindo estímulos por ultra-som, elétrico e eletromagnético, têm levado a bons resultados clínicos, embora ainda sejam desenvolvidos de forma empírica, sem esquemas de dose-efeito bem definidos, principalmente pela falta de compreensão das interações destas técnicas com a membrana celular ${ }^{(2)}$.

De acordo com informações da empresa fornecedora dos tubos piezelétricos, esses tubos foram polarizados com bombardeamento de cargas negativas, ficando assim a parede externa do tubo carregada positivamente e a parede interna negativamente, já que o bombardeamento atraiu as cargas positivas para a parede externa, orientando no interior do material os dipolos e fazendo com que as cargas negativas se concentrassem na parede interna.

Nessas condições, se esse tubo sofresse compressão, cargas positivas seriam geradas em uma das faces e cargas negativas, na outra face. Caso sofresse alongamento, a polaridade das cargas se inverteria. Desse modo, cargas negativas poderiam ser geradas tanto na superfície externa, quanto na superfície interna do tubo, estimulando o crescimento no interior e fora do mesmo.

O tipo e a magnitude da deformação mecânica sofrida pelos tubos neste estudo pode ser questionada, já que por estarem implantados na região metafisária distal dos fêmures, era esperado que não sofressem deformações. Como, então, se pode explicar neste estudo o efeito piezelétrico? Uma das explicações possíveis leva em conta que o tubo de PVDF piezelétrico funcionaria como um eletreto (ou capacitor), que estimularia por si só o crescimento do tecido ósseo, de forma semelhados aos achados de Yasuda ${ }^{(15)} \mathrm{com}$ o teflon polarizado. A
The manner in which the bone tissue interprets the piezoelectric stimulus and transforms it into biological activity is still not clearly explained in the literature, so much as for the difficulty of mimetizing the real environmental conditions of the bone tissue, as for the fact that the knowledge of the intra and extracellular communication mechanisms is still a relatively recent subject. The biology studies during the last decades have been focused on the knowledge of the extracellular signaling molecules, because they make the cells capable of responding to certain incentives. These signaling molecules link to receptor proteins of the cellular surface and later to the intracellular signaling proteins, which direct the signal to appropriate regions of the cell. In the end of this process are the target proteins, that are the final effectors and induce the modification in the cellular behavior ${ }^{(1)}$

Experimental studies have been trying to define which is the molecule or system that translates the language of the physical stimulus into biological language, but until now the most current data on the subject were defined based on experimental studies of cell cultures that, although very useful for the explanation of isolated phenomena, cannot be extrapolated for what happens with the tissue within the body as a whole. According to Roy et al(14), the studies performed during the last 10 years only began to elucidate the aspects of the transmembrane signaling , and the genical expression of the bone tissue in response to biophysical stimuli, as for instance, the alteration in the flow of the canaliculi that link the osteocytes.

The mechanical deformation at physiologic levels can create different hydrostatic pressure gradients in the interstitial fluid of the caniculi of the bone tissue, that are captured by the cellular membrane of the osteocyte, resulting in the increase of its metabolic activity, suggesting that the osteocyte is the responsible cell for the transduction process from the mechanical to the biological stimulus. On the other hand, the in vivo or in vitro studies have also been showing a rather uniform response of the bone tissue regarding the electric stimuli that increase the production and remodeling of the bone. In addition, the therapeutic use of those techniques, including the ultrasound, electric and electromagnetic stimuli have been leading to good clinical results, although they are still developed in an empiric manner, without very defined dose-effect schemes, mainly due to the lack of a better understanding of the interactions between these techniques with the cell membrane ${ }^{(2)}$.

According to information received from supplier of the piezoelectric tubes, those tubes were polarized with the bombardment of negative charges, and thus the outside wall is charged positively and the inside wall negatively, since the bombardment attracted the positive charges to the outside wall, driving in the inside of the material the dipoles and thus making the negative charges concentrated on the inside wall.

Under those conditions, if that tube suffered any compression, the positive charges would be generated on one of the faces and the negative charges, on the other face. In case it suffered a stretching effort, the polarity of the charges would be inverted. In this manner the negative charges could be generated on the outside surface, as well as on the inside surface of the tube, stimulating the growth inside and outside of the tube.

The type and the magnitude of the mechanical deformation that the tubes underwent in this study can be questioned because, as they are implanted in distal metaphysical area of the femurs, it was expected that they didn't suffer any deformations. How, then, can the piezoelectric effect be explained in this study? One of the possible explanations takes into account that the piezoelectric PVDF tube would work as an electret (or capacitor), that it stimulate the growth of the bone tissue by itself, in a similar way as the finding by Yasuda ${ }^{(15)}$ with the polarized Teflon. In favor of that hypothesis is the fact that the bone growth was observed only inside the piezoelectric tubes, where the negative charg- 
favor dessa hipótese, há o fato de que o crescimento ósseo só foi observado no interior dos tubos piezelétricos, onde se concentram cargas negativas. Assim, pode-se supor que mesmo após a manipulação e implantação dos tubos a superfície interna manteve-se carregada, com predomínio de cargas negativas que sabidamente estimulam o crescimento ósseo ${ }^{(2,9)}$.

A outra explicação possível leva em conta o fato de, por estarem implantados na região intercondiliana do fêmur e por esta região ser intra articular, os tubos passaram a sofrer microdeformações com a mudança do gradiente de pressão intra articular, gerada pelo movimento da articulação e durante a marcha. Essas microdeformações devem ter induzido, pelo efeito da piezeletricidade, a formação de correntes elétricas na superfície interna dos tubos, que foram responsáveis pelo crescimento de tecido ósseo, como sugerido por alguns autores $^{(4,6,7,11)}$

Apesar dos resultados deste estudo indicarem que houve efeito positivo do PVDF piezelétricos com relação à neoformação óssea, novas investigações são necessárias para que se possa quantificar melhor esse fenômeno e, do ponto de vista clínico, há necessidade de se avaliar a sua aplicabilidade.

Pode-se concluir que na interface formada entre o tubo de PVDF (piezelétrico e não piezelétrico) com o tecido ósseo não houve crescimento de tecido fibroso e que no interior dos tubos piezelétricos houve formação de tecido ósseo, inclusive com arranjo trabecular. es are concentrated. Therefore, it can be supposed that even after the manipulation and implantation of the tubes the inside surface remained charged, with the prevalence of negative charges that knowingly stimulate the bone growth ${ }^{(2,9)}$.

The other possible explanation takes into consideration the fact that, as they were implanted in the intercondilian area of the femur, and as this is an intra-articular area, the tubes initiated a micro deformation process, due to the change of the intra-articular pressure gradient, generated by the movement of the articulation, and during the gait. Those micro deformations must have induced, due to the effect of the piezoelectricity, the formation of electric currents on the inside surface of the tubes, that were responsible for the growth of bone tissue, as suggested by some authors ${ }^{(4,6,7,11)}$

In spite that the results of this study indicate that there was a positive effect of the piezoelectric PVDF regarding the new formation of bone, new investigations are necessary to better quantify that phenomenon-and, from the clinical point of view, there is the need to evaluate its applicability.

It can be concluded that in the interface formed among the PVDF tube (piezoelectric and non-piezoelectric) with the bone tissue there was no growth of fibrous tissue, and that inside of the piezoelectric tubes there was a formation of bone tissue, including a trabecular arrangement.

\section{REFERÊNCIAS BIBLIOGRÁFICAS}

1. ALBERTS B, JOHNSON A, LAWIS J, REFF M, ROBERTS K, WALTER P. Chapter 15. In: Molecular biology of the cell. 4a'. edição. EUA: Galan \& Science, 2002. 831-906.

2. BRIGHTON CT, WANG W, SELDES R, ZHANG G, POLLACK SR. Signal transduction in electrically stimulated bone cells. J Bone Joint Surg Am, 83-A(10):1514-1523, 2001

3. FROST HM. Orthopaedic Biomechanics. Illinois (EUA), Charles C. Thomas (publisher), 1973, 652p, volume 5

4. HAMAMOTO N, HAMAMOTOY, NAKAJIMA T, OZAWA H. Histological, histocytochemical and ultrastructural study on the effects of surface charge on bone formation in the rabbit mandible. Arch Oral Biol, 40(2): 97-106, 1995.

5. JIANQING F, HUIPINY, XINGDONG Z. Promotion of osteogenesis by a piezoelectric biological ceramic. Biomaterials, 18: 1531-1534, 1997.

6. JONES SJ, BOYDE A. The migration of osteoblasts. Cell Tissue Research. 184: 179193, 1977.

7. KIZUKI T, OHGAKI M, KATSURA M, NAKAMURA S, HASHIMOTO K, TODA Y, UDAGAWA S, YAMASHITA K. Effect of bone-like layer growth from culture medium on adherence of osteoblast-like cells. Biomaterials, 24(6): 941-947, 2003.

8. KLINGEU, KLOSTERHALFEN B, OTTINGERAP, JUNGE K, SCHUMPELICK V. PVDF as a new polymer for the construction of surgical meshes. Biomaterials, 23: $3487-$ 3493, 2002

9. KÖBERLE G. Estudos físicos e biológicos em tecido ósseo. Ribeirão Preto - São
Paulo, 1974. (Tese - Livre docência - Faculdade de Medicina de Ribeirão Preto)

10. LAROCHE G, MAROIS Y, SCHWARZE, GUIDOIN R, KING M, PARIS E, DOUVILLEY Polyvinylidene fluoride (PVDF) as a biomaterial: from polymeric raw material to monofilament vascular suture. J Biomed Mat Res. 29: 1525-1536, 1995.

11. NAKAMURA S, KOBAYASHI T, YAMASHITAK. Extended bioactivity in the proximity of hydroxyapatite ceramic surfaces induced by polarization charges. J Biomedical Mat Res. 61(4): 593-9, 2002

12. PASCHOAL AL. Estudo da viabilidade de aplicação do polímero piezelétrico fluoreto de polivinilideno (PVDF) entre osso cortical e placa de osteossíntese para estimulação de crescimento ósseo. São Carlos/SP. 2003 (Tese - Doutorado Universidade de São Paulo).

13. RIBEIRO PAMF. Influência da umidade nas propriedades elétricas do Fluoreto de Polivinilideno. Lisboa: Universidade Nova de Lisboa - Faculdade de Ciências e Tecnologia, 1994

14. ROY AK, BOYAN BD, CIOMBOR DB, SCHWARTZZ, SIMON B. Stimulation of growth factor synthesis by electric and electromagnetic fields. Clin Orthop Rel Res. 1(419): $30-37,2004$

15. YASUDA I. Electrical callus and callus formation by electret. Clin Orthop Rel Res, 124: 53-56, 1977 